\title{
APLIKASI AKUNTANSI PENERIMAAN KAS ATAS SEWA ALAT BERAT PADA PT. JASA TRANSPORTASI YALA GITHA TAMA CIREBON
}

\author{
Andini Nurmayanti ${ }^{1}$ \\ Universitas Catur Insan Cendekia \\ andini.nurmayanti97@gmail.com \\ Widya Jati Lestari ${ }^{2}$ \\ Universitas Catur Insan Cendekia \\ widya.jatilestari@cic.ac.id \\ Agus Sevtiana $^{3}$ \\ Universitas Catur Insan Cendekia \\ a.sevtiana@gmail.com \\ Rahimah $^{4}$ \\ Akademi Akuntansi YKPN \\ rahimah@aaykpn.ac.id
}

\begin{abstract}
Abstrak - PT. Jasa Transportasi Yala Githa Tama Cirebon merupakan perusahaan jasa yang melayani persewaan Forklift serta Mobile Crane. Dimana alat tersebut digunakan untuk membantu dalam melakukan pekerjaan pembangunan suatu proyek dalam aktivitasnya perusahaan dalam bertransaksi melakukan perjanjian kerja sama dengan mitra secara down payment. Dari kegiatan tersebut, timbul penerimaan kas. Penerimaan kas ini perlu dikelola dengan baik karena unsur pendapatan bagi perusahaan. Penelitian ini bertujuan untuk menganalisa, merancang, dan mengimplementasikan Aplikasi Akuntansi Penerimaan Kas Atas Sewa Alat berat Pada PT. Jasa Transportasi Yala Githa Tama Cirebon yang dapat membantu perusahaan dalam pekerjaannya, sehingga dapat terlihat dalam laporan berapa jumlah yang menjadi uang muka dan berapa jumlah yang menjadi pelunasan. Metode yang digunakan dalam pengembangan program aplikasi berbasis web yang memuat prosedur akuntansi penerimaan kas atas sewa alat berat pada PT. Jasa Transportasi Yala Githa Tama Cirebon. Sistem ini menggunakan bahasa pemrograman PHP sebagai Webserver dan MYSQL sebagai Database dan menggunakan Browser Google Chrome. Hasil rancangan dari penelitian ini dapat mempermudah dalam melakukan pengelolaan data penyewaan alat berat pada penerimaan kas dan membantu kegiatan manajemen sehingga dapat memudahkan bagian administrasi, operasional dan bagian keuangan dalam melakukan aktivitas akuntansi perusahaan. Aplikasi ini menghasilkan berupa laporan pemesanan sewa alat berat, laporan pemakaian sewa alat berat, invoice, laporan penerimaan sewa alat berat dan jurnal umum.
\end{abstract}

Kata Kunci: Aplikasi, Akuntansi, Penerimaan Kas, Down Payment, Alat Berat 


\begin{abstract}
PT. Yala Githa Tama Cirebon Transportation Services is a service company that provides rental services for forklifts and mobile cranes. Where the tool is used to assist in carrying out the construction work of a project in the company's activities in conducting transactions with partners through down payment. From these activities, cash receipts arise. This cash receipt needs to be managed properly because of the income element for the company. This study aims to analyze, design, and implement the Accounting Application for Cash Receipts on Heavy Equipment Rental at PT. Yala Githa Tama Cirebon Transportation Services that can help companies in their work, so that it can be seen in the report how much is the down payment and how much is the amount that is paid off. The method used in the development of a web-based application program that contains accounting procedures for cash receipts for heavy equipment leases at PT. Yala Githa Tama Cirebon Transportation Services. This system uses the PHP programming language as a Webserver and MYSQL as a database and uses the Google Chrome browser. The results of the design of this study can make it easier to manage heavy equipment rental data on cash receipts and assist management activities so that it can facilitate the administrative, operational and financial departments in carrying out corporate accounting activities. This application produces heavy equipment rental order reports, heavy equipment rental usage reports, invoices, heavy equipment rental receipts reports and general journals.
\end{abstract}

Keywords: Applications, Accounting, Cash Receipts, Down Payment, Heavy Equipment

\section{PENDAHULUAN}

PT. Jasa Transportasi Yala Githa Tama Cirebon merupakan perusahaan yang bergerak di bidang penyewaan alat berat seperti forklift, mobile crean dan trucking. Tidak hanya itu, PT. Jasa Transportasi Yala Githa Tama Cirebon juga bergerak di bidang expedisi muatan laut, bongkar muat di pelabuhan, persewaan pergudangan dan ruangan kantor.

Alat berat adalah mesin berukuran besar yang didesain untuk melaksanakan fungsi konstruksi seperti pengerjaan tanah (earthworking) dan memindahkan bahan bangunan. Persaingan dalam pesewaan alat berat khususnya forklift dan Mobile Crane. Dalam pelaksanaan pencapaian kinerja di tahun 2019 PT. Jasa Transportasi Yala Githa Tama Cirebon didukung oleh usaha persewaan alat berat khususnya Forklift yang saat ini secara fisik ada 1 unit (10 ton), 3 unit (5 ton), dan 3 unit (3 ton) serta Mobile Crane
2 unit ( 7 ton), 2 unit (16 ton), 3 unit (20 ton) dan 1 unit (50 ton), dengan dibarengi strategi-strategi pemasaran yang diterapkan oleh manajemen mendorong kinerja perusahaan yang dalam melakukan semua kegiatan berdasarkan prinsip-prinsip transparasi, akuntabilitas, tanggung jawab dan kewajaran. Dengan pengelolaan yang baik ini maka PT. Jasa Transportasi Yala Githa Tama Cirebon diharapkan mampu meningkatkan profit perusahaan.

Pada prinsipnya pengelolaan keuangan sangatlah penting bagi setiap perusahaan begitu pula pada PT. Jasa Transportasi Yala Githa Tama Cirebon, Menurut Widya (2020) (khususnya penerapan sistem pengeluaran kas, dan penerimaan kas) mengingat kas digunakan untuk membiayai biaya operasional perusahaan. . Untuk mengawasi pengeluaran kas, maka diperlukan pengendalian yang baik terhadap kas dan memerlukan prosedur prosedur yang memadai untuk 
melindungi pengeluaran kas. Dalam melakukan kegiatan akuntansi perusahaan masih dilakukan secara manual, dimana dalam penyewaan alat berat mitra yang ingin bekerja sama dengan perusahaan ini harus membuat surat permintaan dan di serahkan via email kepada perusahaan untuk disetujui. Perusahaan ini memiliki administrasi operasional yang ditugaskan untuk membuat surat penawaran sewa alat berat, jika konsumen tidak menyetujui dengan surat penawaran yang ada mitra meminta kesepakatan harga sesuai dengan permintaan. Terkadang mitra juga meminta kesepakatan harga, konsumen harus bertemu secara langsung bahkan konsumen ingin meminta bertemu diluar kantor. Sehingga membutuhkan waktu, biaya, dan tenaga yang tidak sedikit. Jika konsumen atau keduanya setuju dengan kesepakatan yang ada maka perusahaan akan mengirim alat berat ke lokasi kerja.

Mitra yang menerima alat berat tersebut harus membayar uang muka (Down payment) sesuai dengan kesepakatan kepada perusahaan dan bagian keuangan membuat pembukuan uang muka (Down Payment) dari konsumen. Administrasi operasional selalu mencatat laporan jam kerja setiap harinya dan laporan pemesanan sewa alat berat diserahkan kepada Keuangan. Keuangan membuat invoice dan laporan penerimaan sewa alat berat, laporan sewa alat berat masih menggunakan Microsoft Excel, kemudian diserahkan kepada mitra dan perusahaan. Sehingga mitra bisa membayar sesuai dengan laporan ini dan diterima langsung oleh bagian keuangan. Pembayaran pelunasan dilakukan dengan via Transfer antar Bank dan pembayaran tersebut masuk ke rekening perusahaan sesuai dengan perjanjian sewa alat berat Kemudian bagian keuangan langsung membuatkan laporan penerimaan sewa alat berat untuk diserahkan sebagai arsip perusahaan.

Proses penyewaan ini dapat dikonfirmasikan secara online dengan teknologi sehingga nantinya akan membantu PT. Jasa Transportasi Yala Githa Tama Cirebon dalam Laporan pemesanan sewa alat berat dan membuat laporan penerimaan sewa alat berat serta invoice, kemudian setiap data akan tersimpan secara rapi dalam sebuah database.

\section{KAJIAN LITERATUR}

Aplikasi adalah suatu program yang siap untuk digunakan yang dibuat untuk melaksanakan suatu fungsi bagi pengguna aplikasi serta pengguna aplikasi lain yang digunakan oleh sasaran yang akan dituju. (Juansyah,2015). Menurut Mulyadi (2016:47), sistem akuntansi dapat dijelaskan dengan menggunakan bagan alir dokumen. Untuk menggambarkan aliran dokumen dalam sistem tertentu, digunakan simbol-simbol dalam suatu bagan alir dokumen (Document Flowchat). Dalam bagan alir, arus dokumen digambarkan berjalan dari kiri ke kanan dan dari atas ke bawah. Arah perjalanan dokumen ini dapat diikuti dengan melihat nomor dalam simbol penghubung pada halaman yang sama (On-Page Connector) atau nomor dalam simbol penghubung pada halaman yang berbeda (Off-Page Connector).

Flowmap mempunyai fungsi sebagai mendefinisikan hubungan antara bagian (pelaku proses), proses (manual/berbasis komputer) dan aliran data (dalam bentuk dokumen keluaran dan masukan). Pengertian Flowmap adalah campuran peta dan Flowchart, yang menunjukkan pergerakan benda dari satu lokasi ke lokasi lain, seperti jumlah orang dalam migrasi, jumlah barang yang diperdagangkan, atau 
jumlah paket dalam jaringan. Flowmap menolong analisis dan Programer untuk memecahkan masalah ke dalam segmensegmen yang lebih kecil dan menolong dalam menganalisis alternatif-alternatif lain dalam pengoperasian. Flowmap dapat dikatakan sebuah aliran data berbentuk dokumen atau formulir di dalam hubungannya dengan kebutuhan data dan informasi. Proses aliran dokumen ini dapat terjadi dengan entitas diluar sistem.

Menurut Mulyadi (2016:45), Bagian alir data adalah suatu model yang menggambarkan aliran data dan proses untuk mengelola data dalam suatu sistem. Bagian alir yang baik dan jelas memerankan bagian yang penting dalam perancangan sistem informasi yang kompleks dan pengembangan program komputer.

Context Diagram adalah data flow diagram yang menggambarkan garis besar operasional sistem. Konteks diagram menggambarkan hubungan sistem dengan entitas-entitas diluar sistem. CD memperlihatkan sistem sebuah proses. Tujuannya adalah memberikan pandangan umum sistem, CD memperlihatkan sebuah proses yang berinteraksi dengan lingkungan luar. Ada pihak yang memberikan masukan dan pihak yang menerima keluaran sistem. (Iswandy,2015).

Entity Relationship Diagram (ERD) merupakan suatu alat untuk mempresentasikan model data yang ada pada sistem dimana didalam-Nya terdapat Entity dan Relationship yang masing-masing dilengkapi dengan atribut-atribut yang mempresentasikan seluruh fakta dari dunia nyata yang digambarkan dengan lebih sistematis dengan menggunakan diagram (Astiti, 2015).

Perangkat lunak yang digunakan Basis Data (Database) dapat didefinisikan sebagai himpunan kelompok data yang saling berhubungan yang diorganisasikan sedemikian rupa agar kelak dapat dimanfaatkan kembali dengan cepat dan mudah. (Hidayatullah dan kawistara, 2017:142). MySQL adalah suatu jenis database yang banyak digunakan untuk membuat aplikasi Web yang dinamis.

Hypertext Preprocessor atau lebih akrab dengan sapaan PHP merupakan bahasa pemrograman script server-side yang di desain untuk pengembangan web. PHP disebut bahasa pemrograman server-side karena diproses pada komputer server. Hal ini berbeda dengan bahasa pemrograman client-side seperti Javascript yang di proses di dalam web browser. PHP merupakan salah satu bahasa pemrograman yang berjenis server-ride. Kode PHP akan di proses oleh server kemudian ditampilkan di dalam browser. Oleh karena itu, salah satu tool yang harus dimiliki sebelum menjalankan PHP adalah server. XAMPP adalah perangkat lunak bebas yang mengandung banyak sistem operasi, merupakan komplikasi dari beberapa program. (Syifani dan Dores 2018:25).

Sistem Akuntansi adalah organisasi formulir, catatan, dan laporan yang dikoordinasi sedemikian rupa untuk menyediakan informasi dengan keuangan yang di butuhkan oleh manajemen guna memudahkan pengelolaan perusahaan.

Metode yang digunakan dalam pengembangan sistem tugas akhir ini adalah metode waterfall. Alasan menggunakan metode ini adalah karena metode waterfall melakukan pendekatan secara sistematis dan berurutan dalam membangun suatu sistem. Proses metode waterfall yaitu pada pengerjaan dari suatu sistem dilakukan secara berurutan. Sistem yang dihasilkan akan berkualitas baik, dikarenakan pelaksanaannya secara bertahap 
sehingga tidak terfokus pada tahap tertentu.

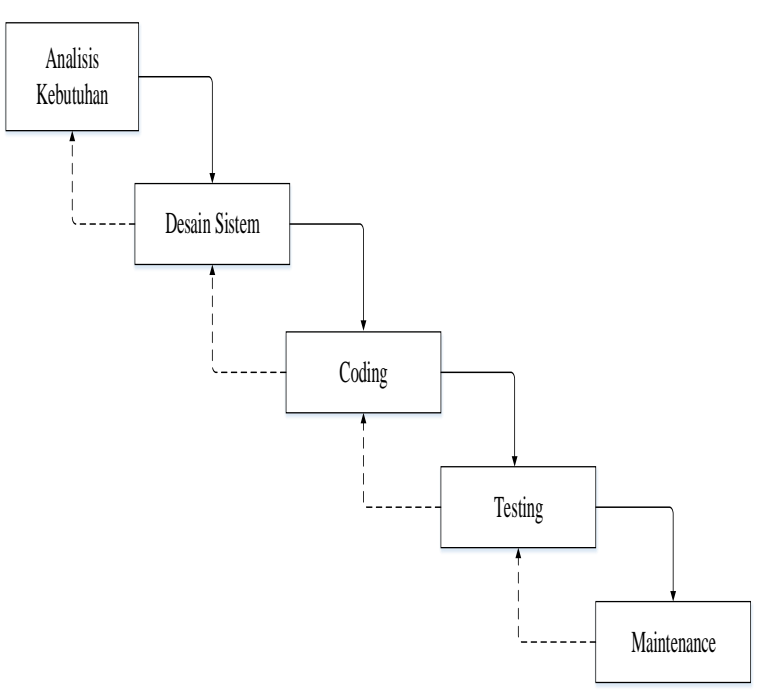

Gambar 1. Metode Waterfall

\section{METODE PENELITIAN}

Adapun Layanan jasa sewa alat berat yang ada di PT. Jasa Transportasi Yala Githa Tama Cirebon adalah sebagai berikut:

\section{Forklift}

Mesin Forklift adalah material hadling yang digunakan sebagai alat bantu untuk mengangkat,menurunkan, memindahkan barang khususnya untuk barang-barang berat dan bisa juga seperti alat transportasi.

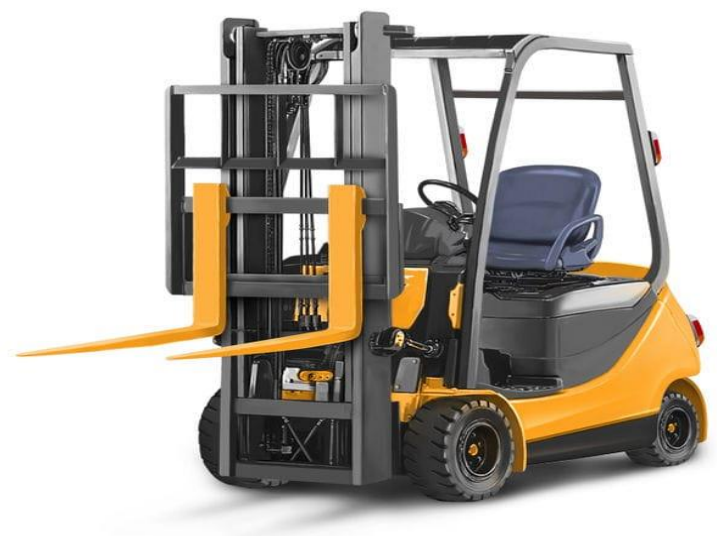

Berikut ini merupakan harga sewa peminjaman forklift :

Tabel 1. Harga Sewa Forklift

\begin{tabular}{|c|c|c|c|c|c|c|}
\hline \multirow{2}{*}{ Nama Alat Ber } & \multirow{2}{*}{ kapasitas } & \multirow{2}{*}{$\begin{array}{l}\text { Jumlah } \\
\text { Un't }\end{array}$} & \multirow{2}{*}{$\begin{array}{l}\text { Biala } \\
\text { Per Jam }\end{array}$} & \multicolumn{3}{|c|}{ Sewa Alat Per Shif } \\
\hline & & & & 1 shiff(8jam) & $2 \operatorname{shif}(16 \mathrm{jm})$ & $3 \mathrm{shif}(24 \mathrm{jam})$ \\
\hline \multirow{4}{*}{ Fooklilt } & 3 ton & 3unit & Rp 250.000 & Rp 2.000.000 & Rpt.000.000 & Rp $\quad 6.0000 .000$ \\
\hline & 5 ton & 3unit & Rp 312.500 & $\operatorname{Rp} 25000.000$ & Rpj.000.000 & Rp $\quad 7.500 .000$ \\
\hline & 7 ton & 1 unit & $\operatorname{Rp} 437.50$ & $\operatorname{Rip} 35.500 .000$ & Rp7.000.000 & $\operatorname{Rp} \quad 10.5000000$ \\
\hline & 10 ton & 1 unit & $\operatorname{Rp} 562500$ & $\operatorname{Rp} \quad 4,5000000$ & Rpg9.000.000 & $\operatorname{Rp} \quad 1350000000$ \\
\hline
\end{tabular}

\section{Mobil Crane}

Mobile Crane merupakan alat berat berupa truk atau sejenisnya untuk melakukan pengangkutan material baik dalam arah horizontal maupun vertikal yang dapat berpindah dari satu tempat ke tempat lain atau melakukan mobilitas.

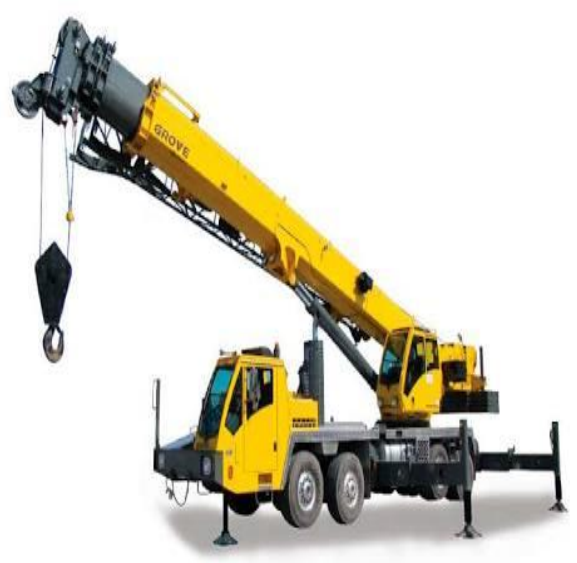

Gambar 2. Mobil Crane

Berikut ini merupakan harga sewa peminjaman forklift :

Tabel 2

Harga Mobil Crane 


\begin{tabular}{|c|c|c|c|c|c|c|}
\hline \multirow{2}{*}{ Vlama Ahat Beral } & \multirow{2}{*}{ kapasitas } & Jumlah & Biala & \multicolumn{3}{|c|}{ Sewa Alat Per Shif } \\
\hline & & Un't & Perlam & $1 \sin (f) \mathrm{jam})$ & $2 \operatorname{sinf}(16 \mathrm{jam})$ & $3 \operatorname{sif}(2 \mathrm{~g}$ am $)$ \\
\hline \multirow{4}{*}{ MobileCrane } & 7 ton & 2unit & Rp 977.50 & $\operatorname{Rp} \quad 7.5000 .000$ & Rpp15.000.000 & Rp 22.500,000 \\
\hline & 16 ton & 2unit & Rpi.1062,50 & $\operatorname{Rp} \quad 8.5000 .000$ & Rpp17,000,000 & Rp 25.500.000 \\
\hline & 20 ton & 3 unit & Rp 1.150:000 & $\operatorname{Rp} \quad 10.000 .000$ & Rp2000000000 & Rp 30.000.000 \\
\hline & 50 ton & 1 unit & Rpl.500.000 & $\operatorname{Rp} 120.000 .000$ & Rp24.000.000 & Rp 36:0000.000 \\
\hline
\end{tabular}

\section{Flowchart Manual}

Berikut merupakan sistem berjalan/manual yang digunakan oleh perusahaan tersebut.

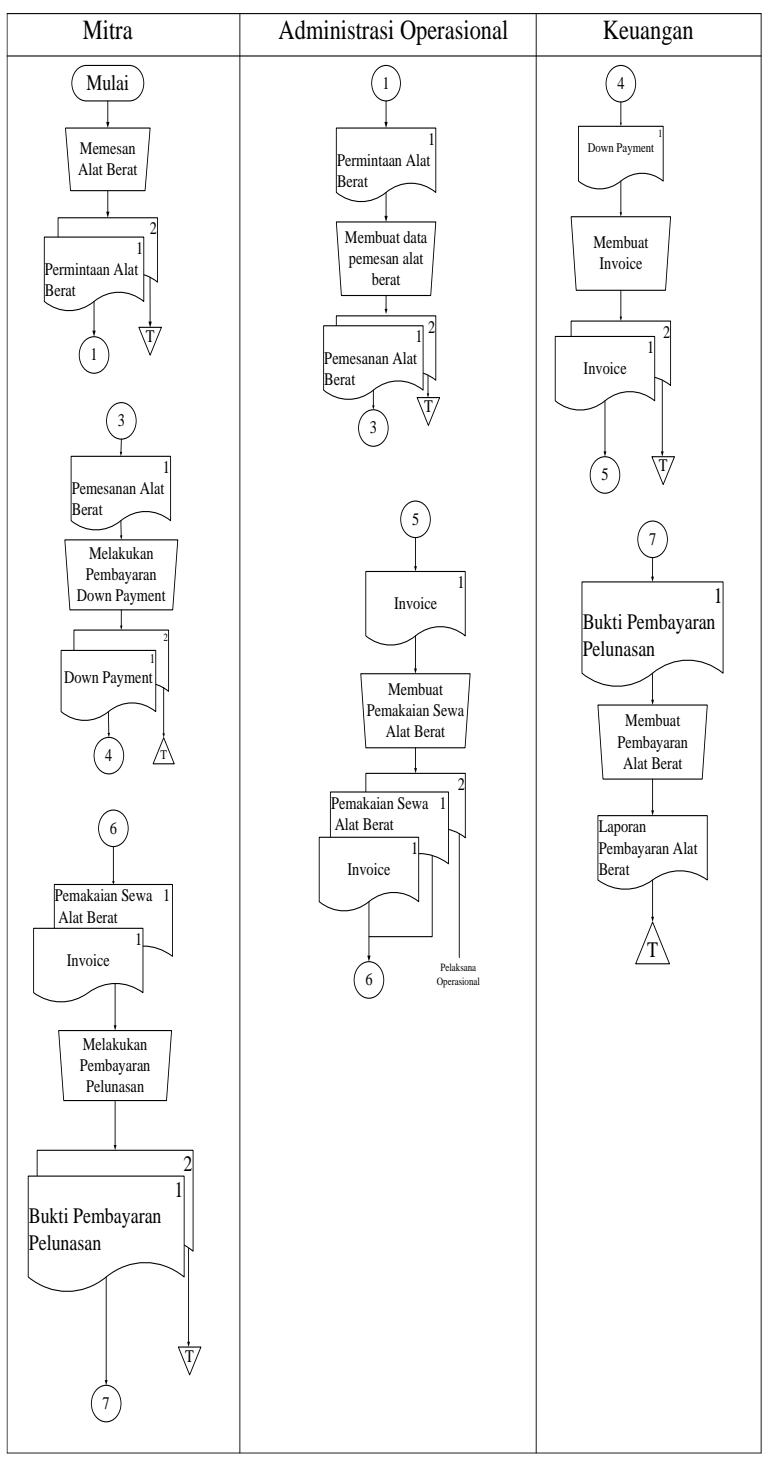

Gambar 3. Flowchart Manual Aplikasi Penerimaan Kas

\section{Flowmap Usulan}

Dimulai dari Bagian Administrasi operasional mengimput data mitra yang menghasilkan informasi data mitra, kemudian mengimput data alat berat, data spesifikasi, data waktu, data harga, dan data mobilisasi yang di perlukan untuk mengimput rekap alat berat yang menghasilkan laporan pemesanan Alat Berat. Mengimput sewa alat berat jika terjadi penyewaan alat berat dan menghasilkan laporan pemakaian sewa alat berat.

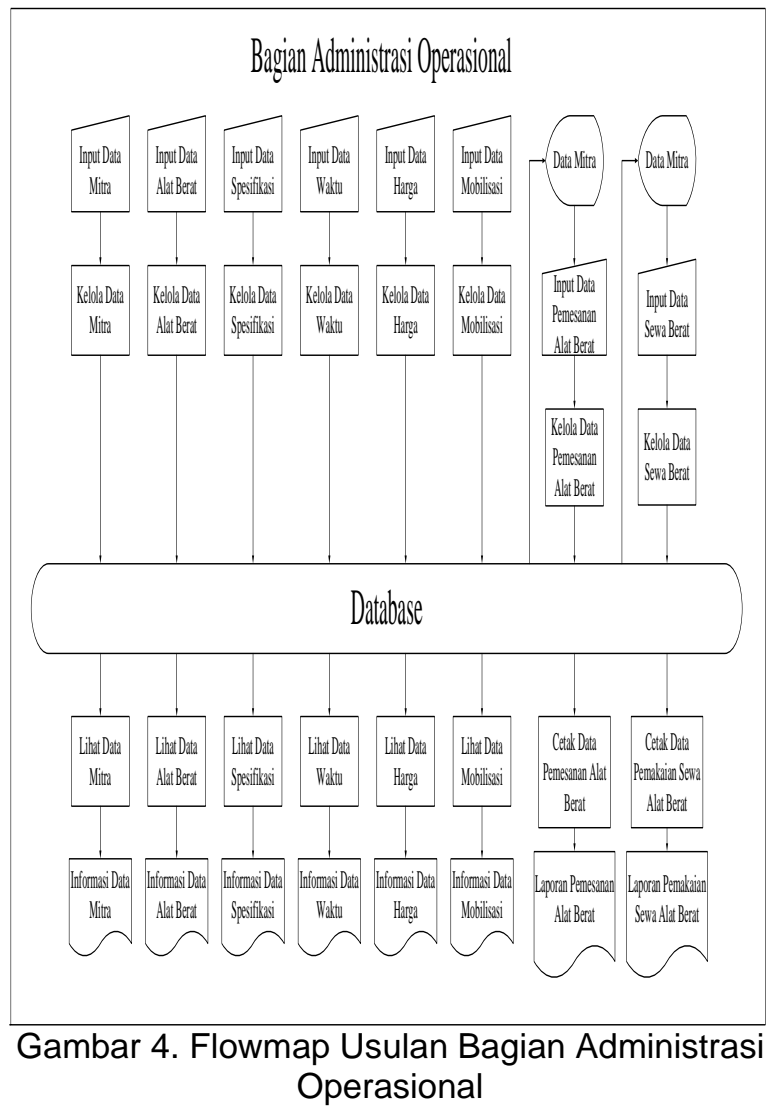

Kemudian Bagian Keuangan menginput data invoice yang dilihat dari data pemesanan per mitra dan menghasilkan invoice. Kemudian mengimput Data Penerimaan Alat Berat harian per mitra yang bisa di update jika terjadi transaksi dan menghasilkan Laporan penerimaan Sewa alat Berat dan mengelola data jurnal. 


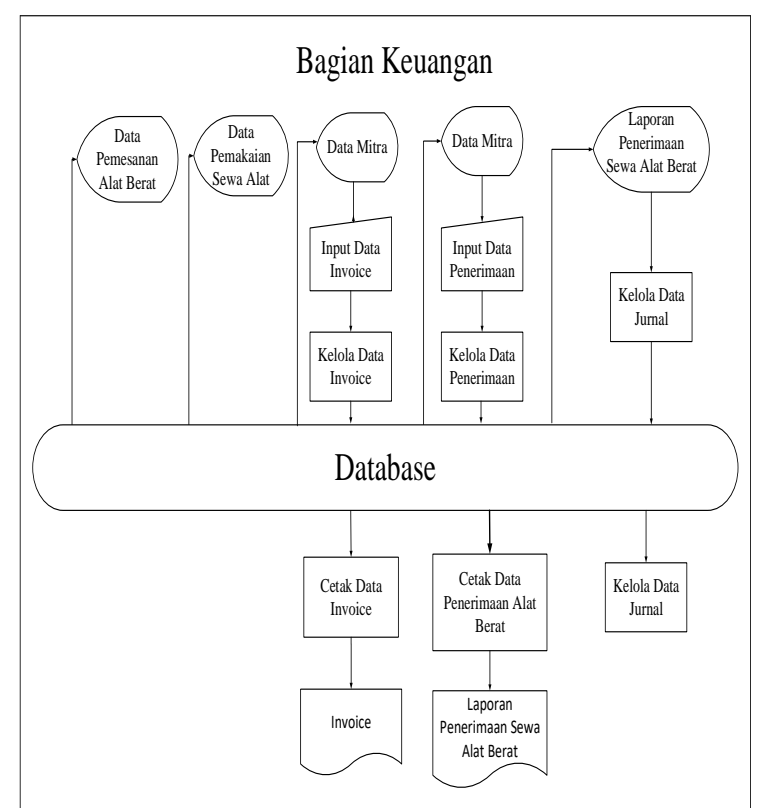

Gambar 5. Flowmap Usulan Bagian Administrasi Operasional

\section{Diagram Konteks}

Menggambarkan siklus akuntansi pencatatan penerimaan kas sewa alat berat, bagian yang terkait yaitu Bagian Administrasi Operasional, dan Bagian Keuangan.

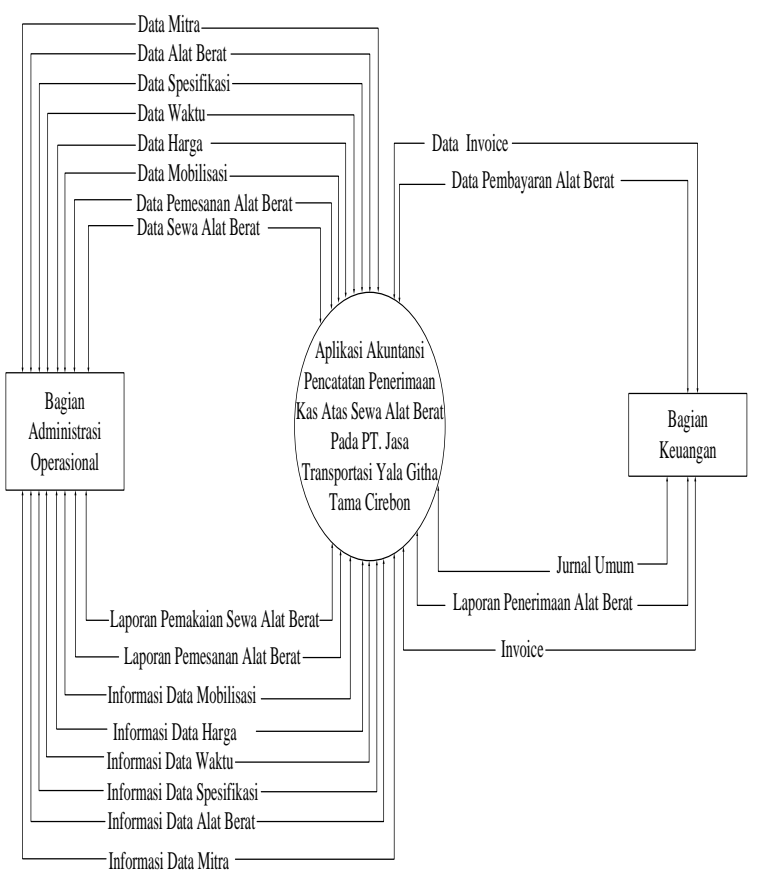

Gambar 6.

Diagram Konteks Aplikasi

\section{Data Flow Diagram}

Menggambarkan garis besar operasional sistem. Konteks diagram menggambarkan hubungan sistem dengan entitas-entitas diluar sistem. Diagram ini memperlihatkan sistem sebuah proses. Tujuannya adalah memberikan pandangan umum sistem, memperlihatkan sebuah proses yang berinteraksi dengan lingkungan luar.

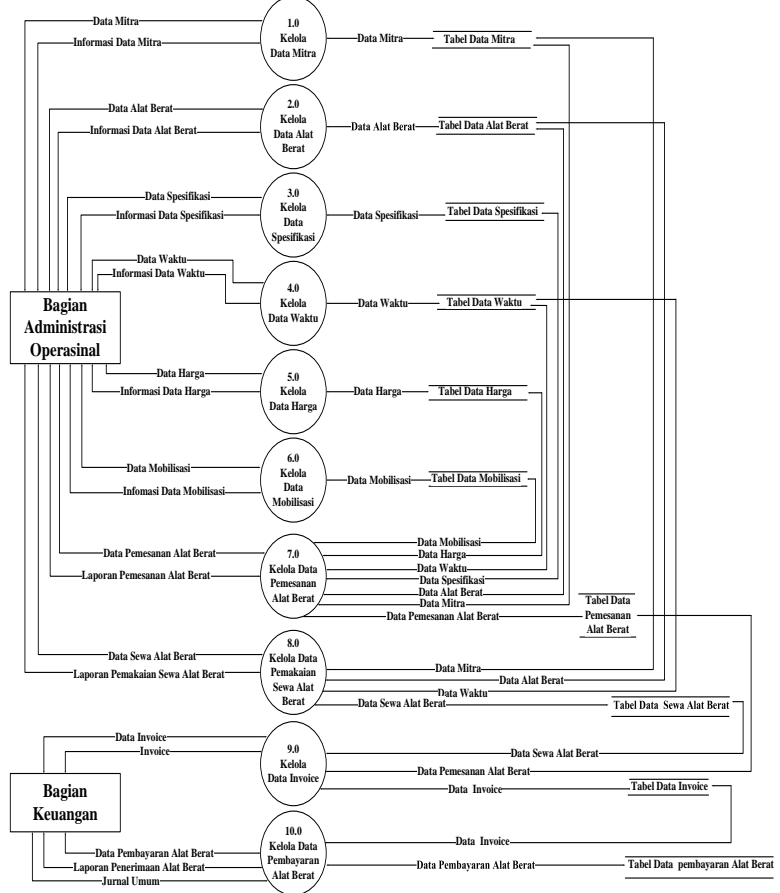

Gambar 7.Data Flow Diagram Aplikasi

\section{Entity Relationship Diagram (ERD)}

Menggambarkan hubungan antara entitas yang ada pada sebuah sistem. Entitas tersebut digambarkan beserta atribut-atributnya yang menggambarkan sebuah aktivitas tersebut, berikut ini adalah Entity Relationship Diagram (ERD) Aplikasi Akuntansi Penerimaan Kas Atas Sewa Alat Berat Pada PT. Jasa Transportasi Yala Githa Tama Cirebon. 


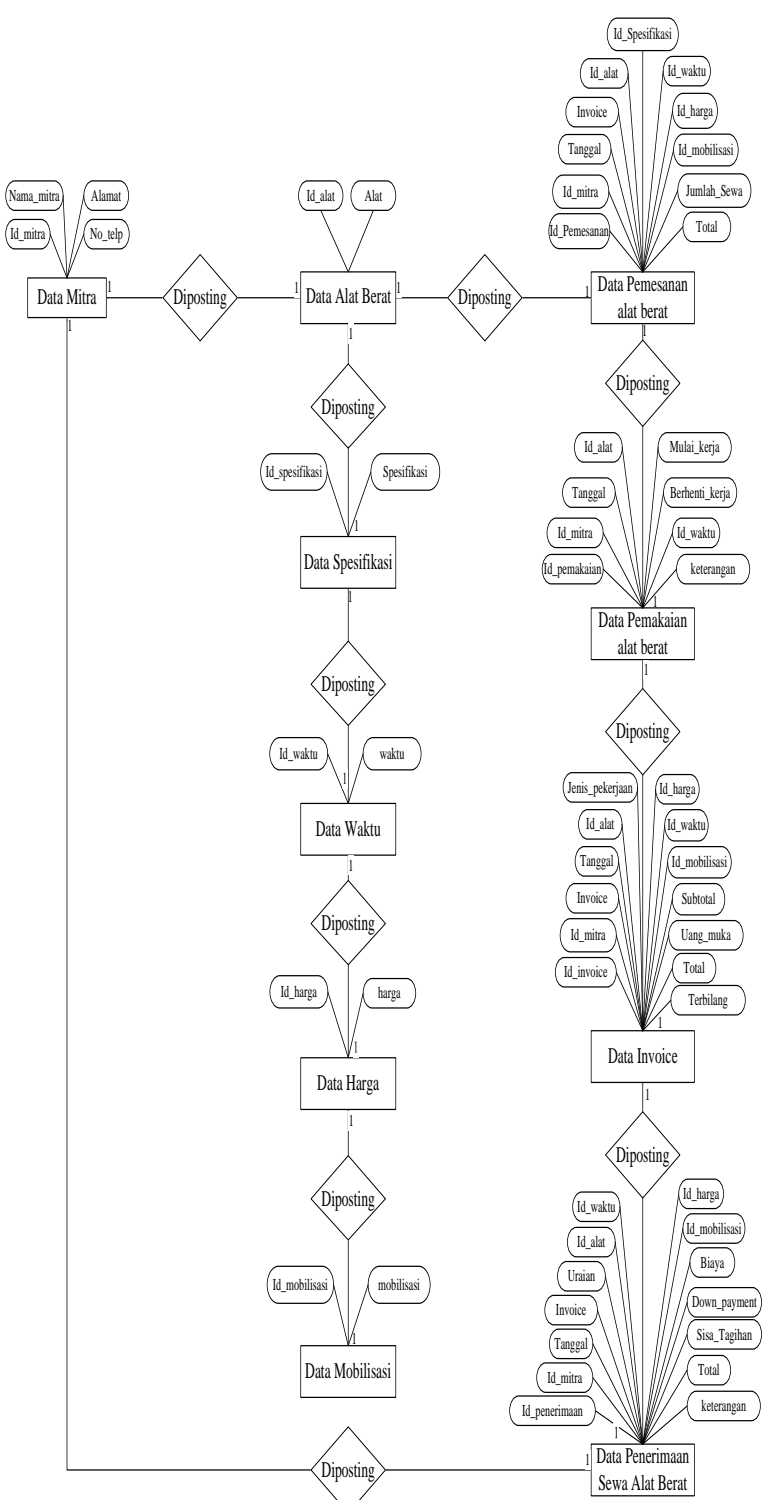

Gambar 8. Entity Relationship Diagram (ERD) Aplikasi

\section{Relasi Antar Tabel}

Perancangan Database (basis data) merupakan salah satu tahap dalam pembuatan aplikasi. Berikut ini merupakan rancangan tabel Aplikasi Akuntansi Pencatatan Penerimaan Kas Atas Sewa Alat Berat PT. Jasa Transportasi Yala Githa Tama Cirebon.

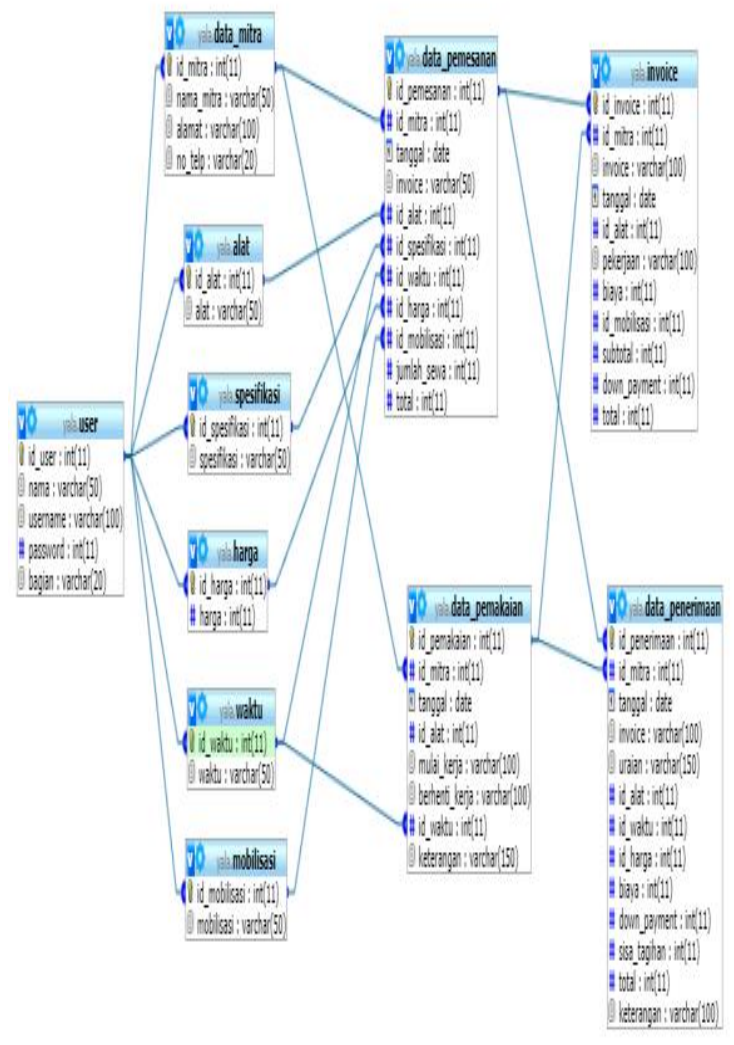

Gambar 9. Relasi Antar Tabel

\section{Interface Design}

Rancangan Tampilan Login

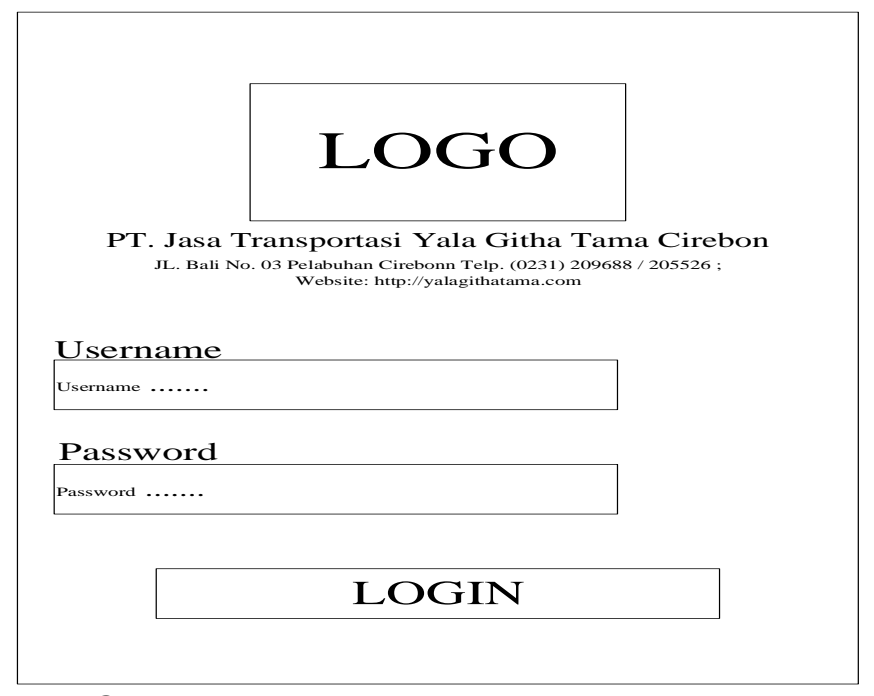

Gambar 10. Rancangan Tampilan Logo

Tampilan Menu Administrasi 


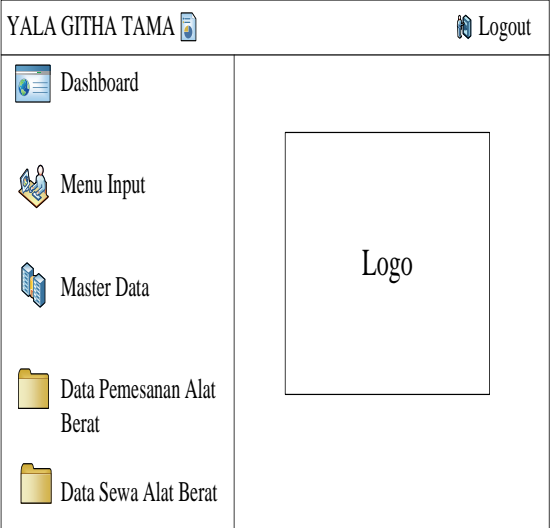

Gambar 11. Tampilan Menu Administrasi

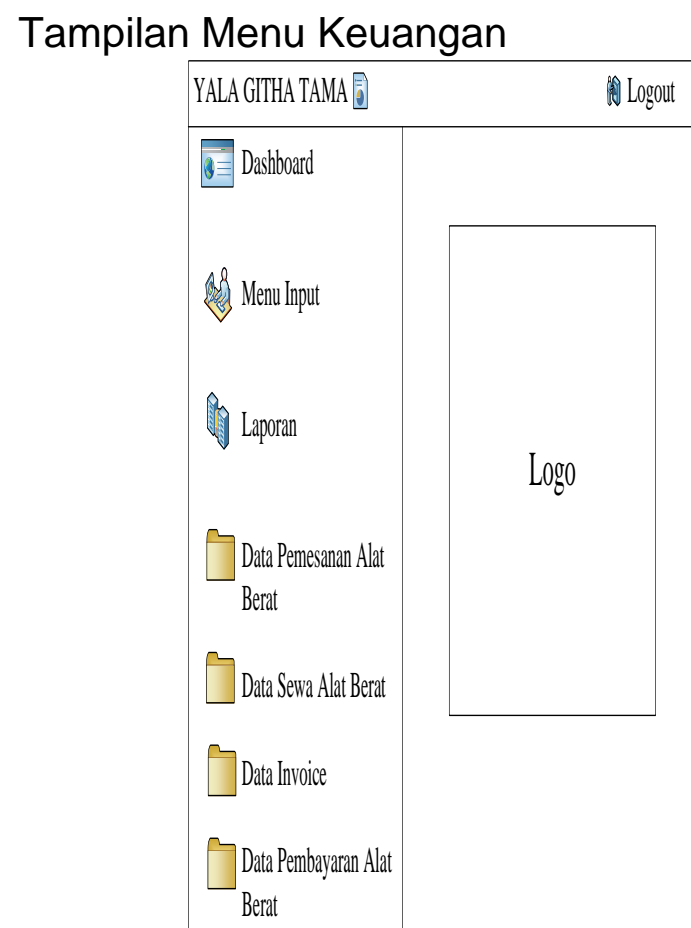

Gambar 12. Tampilan Menu Administrasi

\section{PENUTUP}

Setelah melalui tahap analisa, perancangan, dan implementasi maka penulis menarik kesimpulan sebagai berikut. Dari aplikasi pencatatan penerimaan kas ini menghasilkan output berupa laporan Pemesanan Alat Berat, Laporan Pemakaian Sewa Alat Berat, Invoice, dan Laporan Pembayaran Alat Berat, jurnal umum.

Prosedur yang digunakan dalam aplikasi ini adalah prosedur Pencatatan Penerimaan Kas Atas Sewa Alat Berat
Pada PT. Jasa Transportasi Yala Githa Tama Cirebon.

Sistem pengendalian internal pada PT.Jasa Transportasi Yala Githa Tama Cirebon sudah cukup baik karena setiap kegiatan dilakukan oleh bagian-bagian yang ada sesuai dengan tugasnya masing-masing dan dokumen diotorisasi oleh pihak yang berwenang setiap bagian sudah memiliki login akses.

Dalam pengembangannya Aplikasi ini dapat digabungkan dengan Aplikasi Akuntansi Pengeluaran Kas PT. Jasa Transportasi Yala Githa Tama Cirebon sehingga dapat menghasilkan satu aplikasi yang terintegrasi antara penerimaan dan pengeluaran. Aplikasi ini masih perlu pengembangannya dalam buku besar. Aplikasi ini belum menghasilkan stock forklift dan mobile crean di PT. Jasa Transportasi Yala Githa Tama Cirebon.

\section{Daftar Pustaka}

Analisis Pemilihan Alat Berat Hiost dan Mobile Crean Pada Pekerjaan Rangka Atap Baja Proyek Pembangunan Fakultas Umum Ull, Hafiz Farid Nurdiansyah 2019.

Hendrik Fengky, Harijanto Sabijono, Melly Kalola, "Evaluasi Penerapan Sistem Pengendalian Internal Penerimaan Kas Pada Hotel Yura Manado" Vol 07 no.01 Janari 2019 Hal 1001-1010.

Mohammad Syamsul Azis, Lukman Hakim, "Perancangan Aplikasi Berbasis Dekstop Dengan Microsoft Visual Basic". Riset Bisnis dan Informatika 2 Hal 44-52, 2020.

Lestari, Jati Widya. 2020. "Aplikasi Akuntansi Pencatatan Pengeluaran Kas Pada PT. Jasa Transportasi Yala Githa Tama". Jurnal Digit. Vol 10 No 2. Halaman 165-284. 
Mulyadi 2016, Sistem Akuntansi, Edisi 4 Jakarta : Salemba Empat.

Rudi Aprianto, Wulan Dari, Nurul Hafifah, "Pengembangan Aplikasi Web Mobile, JTKSI, Vol 01 No.03 Hal 81-86.
Usulan Perancangan Perawatan Mesin Forklift dengan Metode Reability Cented, Maintenancedi PT. Indospring Tbk, Ikhwan, Deny Andesta, Elly Ismiah 2018. 